Article

\title{
Toxicity of Ochratoxin to Early Life Stages of Zebrafish (Danio rerio)
}

\author{
Linda Tschirren, Seraina Siebenmann and Constanze Pietsch * \\ Institute of Natural Resource Sciences (IUNR), Zurich University of Applied Sciences (ZHAW), Grüental, \\ P.O. Box, CH-8820 Wädenswil, Switzerland; linda.tschirren@zhaw.ch (L.T.); siebeser@students.zhaw.ch (S.S.) \\ * Correspondence: constanze.pietsch@zhaw.ch; Tel.: +41-58-934-5613
}

Received: 30 April 2018; Accepted: 22 June 2018; Published: 28 June 2018

\begin{abstract}
Ochratoxin A (OTA) is a known contaminant in fish feed but its effect on fish health remains rather unknown. A study was conducted to investigate the effects of different concentrations of ochratoxin on early life stages of zebrafish (Danio rerio). The tests with ochratoxin A showed a correlation between the exposure to mycotoxin and the amount of damage. The mortality rate and the incidents of embryonal damage was increased by increasing ochratoxin concentrations. The calculations resulted in a lethal concentration for $50 \%$ of the embryos $\left(\mathrm{LC}_{50}\right)$ of $0.29 \mathrm{mg} / \mathrm{L}$ and a concentration at which $50 \%$ of the animals showed impairment $\left(\mathrm{EC}_{50}\right)$ of $0.36 \mathrm{mg} / \mathrm{L}$ after $96 \mathrm{~h}$ of exposure. During the test, reduced heart rates were also observed revealing a clear dose-response relationship. The $\mathrm{EC}_{50}$ determination for this endpoint was $1.26 \mathrm{mg} / \mathrm{L}$ after $72 \mathrm{~h}$ of exposure. The measurement of oxidative stress was proven to be the most sensitive system to indicate OTA effects on the zebrafish embryos with an $\mathrm{EC}_{50}$ value of $0.067 \mathrm{mg} / \mathrm{L}$ after $72 \mathrm{~h}$ of exposure. The test validity was given because the control test with 3,4-Dichloroaniline (3,4-D) showed a $\mathrm{LC}_{50}$ value of $2.88 \mathrm{mg}$ after $96 \mathrm{~h}$ of exposure which is comparable to the available reference values. According to the current knowledge, these experimental doses did not exceed the environmental concentrations of this ochratoxin A. However, this study raises concerns about the effects of ochratoxin on fish.
\end{abstract}

Keywords: mycotoxin; embryo toxicity; heart rates; oxidative stress

Key Contribution: This study confirms that ochratoxin A impairs the development and hatching success of fish embryos, and its possible mechanism of action in the embryos is related to production of oxidative stress.

\section{Introduction}

Ochratoxin A (OTA) is mainly produced by fungi of the genus Aspergillus and Penicillium. As a consequence of their world-wide occurrence, OTA has been found in feed ingredients and feeds at variable contamination levels which are assumed to be caused by differences in to humidity and temperature during crop growth and during storage of feed ingredients and compounded feeds [1-3]. The contamination with OTA has to be taken seriously since OTA is assumed to be more stable in the environment than, for example aflatoxins [2,4]. Contaminated feed products lead to the introduction of OTA in the food chain and a risk for humans is assumed [5]. The presence of OTA in the food chain also resulted in detectable OTA levels in humans [6]. In addition, waste water is produced at different steps during wine production and winery effluents have been shown to contain considerably high concentrations of OTA $[7,8]$ which might be an additional point source of OTA for aquatic environments. The effects of OTA in vertebrates are therefore of great concern.

In higher vertebrates, toxic effects of OTA are mainly observed in the kidney and liver and OTA was also reported to be teratogenic and immunotoxic [9]. In rodents, carcinogenic effects have also been 
observed [10]. In animals, therefore, a higher susceptibility to disease and more secondary infections have been observed [9] Embryotoxicity has been shown in amphibians and rats, mice, hamsters and chickens [11-15]. In addition, exposure of zebrafish embryos to OTA resulted in a variety of severe abnormalities, such as deformities, reduced growth and hatching rates and lethality at concentrations as low as $0.1 \mathrm{mg} / \mathrm{L}$ exposure medium [16]. Furthermore, the injection of rainbow trout with OTA resulted in kidney and liver damage and the calculation of a lethal concentration for $50 \%$ of the animals $\left(\mathrm{LC}_{50}\right)$ after $96 \mathrm{~h}$ of exposure to OTA of $4.7 \mathrm{mg} / \mathrm{kg}$ body weight [17]. Dietary exposure of channel catfish (Ictalurus punctatus) and sea bass (Dicentrarchus labrax) to OTA led to reduced weight gains, poorer feed conversion rates, lower survival and changes of haematocrit values [5,18] in these fish species but not in Atlantic salmon (Salmo salar [19]). In addition, histopathological damage in the liver and posterior kidney and changes of immune parameters were observed in channel catfish $[5,20,21]$. Similar studies on Nile tilapia (Oreochromis niloticus) showed that increasing dietary OTA levels resulted in decreased growth, feed utilization and nutrient composition of the carcass [22]. In contrast to the investigations on fish, a study on shrimp reported no pronounced negative effects of OTA at levels of up to $1 \mathrm{mg} / \mathrm{kg}$ [23]. In naturally contaminated feeds, OTA commonly occurs together with other mycotoxins [24] but interactions with other toxins have not been reported.

The present study investigated effects of OTA to describe possible threshold values for fish embryo toxicity for this mycotoxin and targets of OTA in zebrafish.

\section{Results}

\subsection{Effects on Zebrafish Embryo Development}

As expected, the embryos after $24 \mathrm{~h}$ of exposure still use the reserves from the yolk sac and do not yet have pigmentation. This exposure duration causes significant damage due to OTA exposure at concentrations higher than $1.25 \mathrm{mg} / \mathrm{L}(p=0.000)$. The detrimental effects of OTA on zebrafish embryos followed a polynomic relationship after $24 \mathrm{~h}$ of exposure $\left(y=0.4595 x^{2}+18.254 x-1.6657\right.$; $\left.\mathrm{r}^{2}=0.97\right)$ and a concentration at which $50 \%$ of the embryos showed any detrimental effects $\left(E_{50}\right.$ value) including death was identified at $2.65 \mathrm{mg} / \mathrm{L}$ (Figure 1A, Table 1). The calculation of a $\mathrm{LC}_{50}$ value at this point in time resulted in a high level with low reliability $\left(\mathrm{LC}_{50}=24.22 \mathrm{mg} / \mathrm{L} ; \mathrm{y}=-0.0106 \mathrm{x}^{2}+\right.$ $\left.1.6564 x+3.6737 ; r^{2}=0.21\right)$. After $48 \mathrm{~h}$, body pigmentation in normal embryos starts; the eye is dark and the yolk sac is further depleted. However, the detrimental effects on the embryos led to a significant developmental retardation at concentrations higher than $0.31 \mathrm{mg} / \mathrm{L}(p=0.011$, Figure $1 \mathrm{~B})$ and the effects showed an $\mathrm{EC}_{50}$ value (integrating all detrimental effects on the embryos including death) of $0.73 \mathrm{mg} / \mathrm{L}\left(\mathrm{y}=-28.917 \mathrm{x}^{2}+121.81 \mathrm{x}-23.178 ; \mathrm{r}^{2}=0.99\right)$ after $48 \mathrm{~h}$ of exposure. The single embryo that showed a conspicuous development in the solvent control had a yolk sac-oedema (Figure 1B), which was no longer detectable after $72 \mathrm{~h}$ and $96 \mathrm{~h}$ of exposure. At $48 \mathrm{~h}$ of exposure, a more reliable $\mathrm{LC}_{50}$ value of $2.57 \mathrm{mg} / \mathrm{L}$ OTA was obtained $\left(\mathrm{y}=3.2147 \mathrm{x}^{2}-7.919 \mathrm{x}+8.3314, \mathrm{r}^{2}=0.88\right)$. After $72 \mathrm{~h}$ of exposure, OTA concentrations higher than $0.31 \mathrm{mg} / \mathrm{L}$ resulted in significant damage to the embryos $\left(p=0.000\right.$, Figure 1C). At this point, an $\mathrm{EC}_{50}$ value (integrating all detrimental effects on the embryos including death) of $0.55 \mathrm{mg} / \mathrm{L}$ was calculated $\left(\mathrm{y}=-24.578 \mathrm{x}^{2}+119.68 \mathrm{x}-9.2249, \mathrm{r}^{2}=0.95\right)$ and $50 \%$ of the animals were found to be dead at $3.32 \mathrm{mg} / \mathrm{L} \mathrm{OTA}\left(\mathrm{y}=3.0667 \mathrm{x}^{2}+4.2717 \mathrm{x}+2.0125, \mathrm{r}^{2}=0.98\right)$.

Table 1. Summary of the $\mathrm{LC}_{50}$ and $\mathrm{EC}_{50}$ values for the respective test durations for embryos exposed to ochratoxin, $n=24$ for each OTA concentration and the solvent control.

\begin{tabular}{cccc}
\hline Time Point & EC $_{\mathbf{5 0}}(\mathbf{m g} / \mathbf{L})$ & LC $_{\mathbf{5 0}}(\mathbf{m g} / \mathbf{L})$ & Ratio $\mathrm{LC}_{\mathbf{5 0}}$ to $\mathrm{EC}_{\mathbf{5 0}}$ \\
\hline $24 \mathrm{~h}$ & 2.65 & 24.22 & 9.14 \\
$48 \mathrm{~h}$ & 0.73 & 2.57 & 3.52 \\
$72 \mathrm{~h}$ & 0.56 & 3.32 & 5.93 \\
$96 \mathrm{~h}$ & 0.29 & 0.36 & 1.24 \\
\hline
\end{tabular}



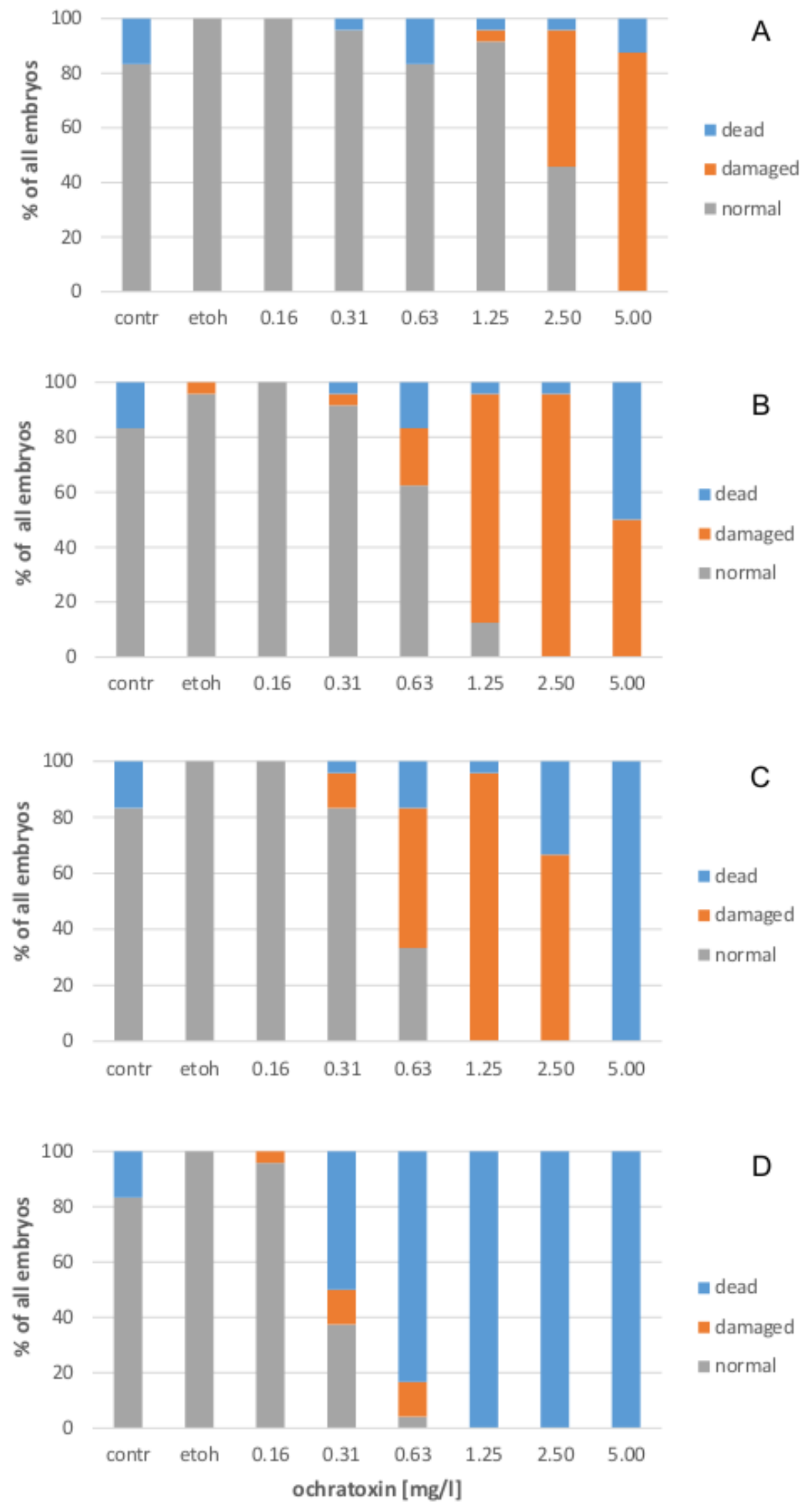

Figure 1. Concentration-dependent effects of OTA on zebrafish embryos after 24 (A), 48 (B), 72 (C) and $96 \mathrm{~h}$ (D) of exposure. 
At $96 \mathrm{~h}$ of exposure, there was a pronounced increase in mortality. Significant effects on zebrafish development were observed at OTA concentrations higher than $0.16 \mathrm{mg} / \mathrm{L}(p=0.000)$. At this point in time, an $\mathrm{EC}_{50}$ value (integrating all detrimental effects on the embryos including death) of $0.29 \mathrm{mg} / \mathrm{L}$ was calculated $\left(y=-0.9341 x^{2}+2.2807 x-0.0455 ; r^{2}=0.96\right)$, whereas the $L_{50}$ value occurred at $0.36 \mathrm{mg} / \mathrm{L}$ OTA $\left(\mathrm{y}=-88.12 \mathrm{x}^{2}+198.92 \mathrm{x}-9.9937, \mathrm{r}^{2}=0.94\right)$. The ratio between the $\mathrm{EC}_{50}$ and $\mathrm{LC}_{50}$ values at each time point did not show a stable ratio (Table 1).

Figure 2 shows embryos in different developmental stages with OTA treatment. After $24 \mathrm{~h}$ of exposure to $5 \mathrm{mg} / \mathrm{L}$ OTA, most embryos showed pronounced retardation of development. These embryos showed a developmental stage that should have been accomplished $16.5 \pm 0.9 \mathrm{~h}$ (mean \pm SEM) earlier according to a previous study ([25], Figure 2A). No further development of these embryos was observed at later points in time and all embryos treated with $5 \mathrm{mg} / \mathrm{L}$ OTA were dead after $72 \mathrm{~h}$ of exposure. The embryos treated for $24 \mathrm{~h}$ with $2.5 \mathrm{mg} / \mathrm{L}$ OTA and $1.25 \mathrm{mg} / \mathrm{L}$ OTA showed a growth retardation of $3.7 \pm 1.3 \mathrm{~h}$ and $0.6 \pm 0.6 \mathrm{~h}$ (means $\pm \mathrm{SEM}$ ), respectively, whereas all remaining fish showed no under-development at this time point. At $48 \mathrm{~h}$ of exposure, $92.2 \%$ of the embryos categorized as damaged embryos (Figure 1B) were underdeveloped. At $72 \mathrm{~h}$ of exposure, different levels of growth retardation were also observed at the lower OTA concentrations (Figure 2B,C). In total, 75.5\% of all embryos listed in Figure 1C showed retardation of the development, whereas the $7 \%$ of the damaged embryos displayed effect on the blood circulation without showing under-development at the same time and the remaining embryos had oedema or had not yet hatched. As an example, the embryo shown in Figure 2B had not developed any pigmentation after $72 \mathrm{~h}$ of exposure to $0.63 \mathrm{mg} / \mathrm{L}$ OTA and showed a level of development comparable to a zebrafish embryo of less than $30 \mathrm{~h}$ after fertilization [25]. A high number of embryos showed deficiencies in blood circulation and the heart development. An example of this is an embryo is shown in Figure $2 \mathrm{C}$ that was treated with $0.31 \mathrm{mg} / \mathrm{L}$ OTA for $72 \mathrm{~h}$.
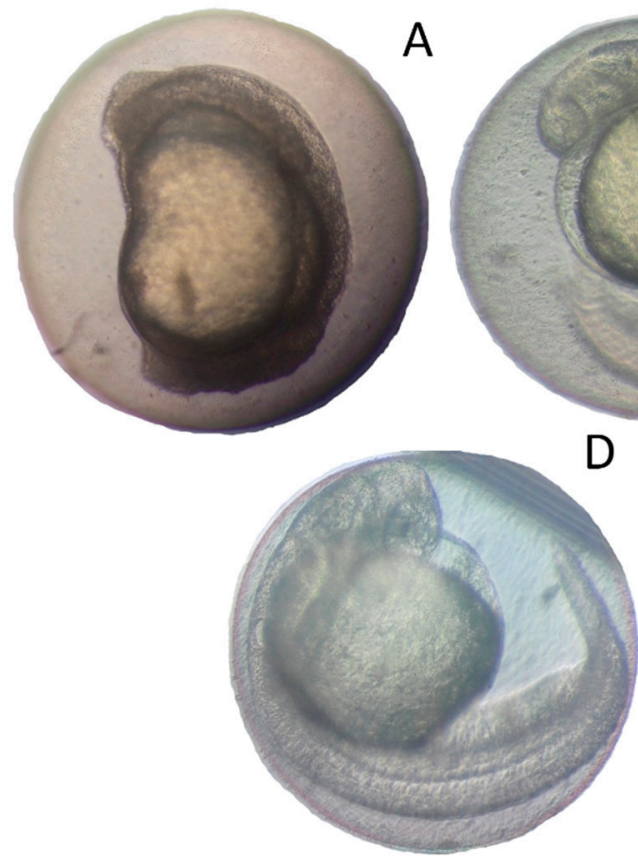

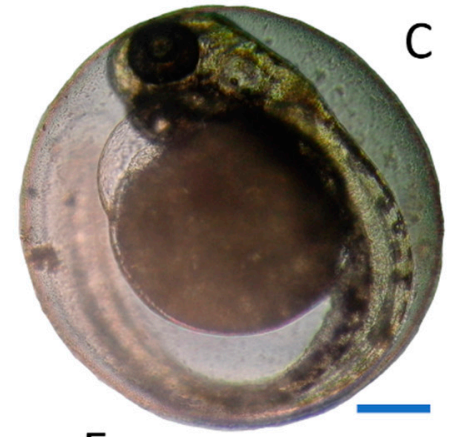

$\mathrm{E}$
B

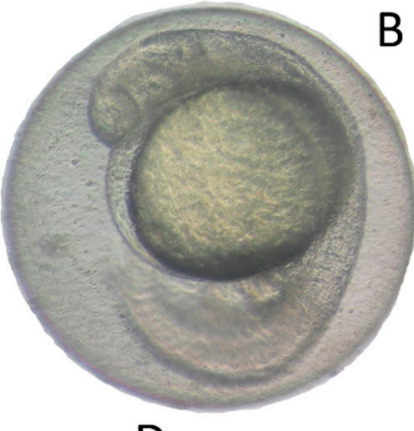

D

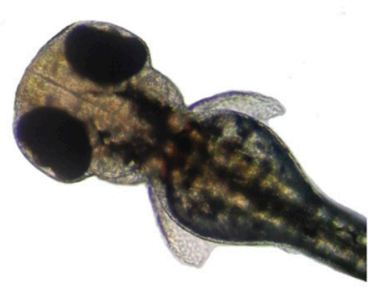

Figure 2. Zebrafish embryos after $24 \mathrm{~h}$ of exposure to OTA at a concentration of $5 \mathrm{mg} / \mathrm{L}$ (A) and after $72 \mathrm{~h}$ of exposure to $0.63 \mathrm{mg} / \mathrm{L}$ OTA (B) and to $0.31 \mathrm{mg} / \mathrm{L}$ OTA (C) showing the retardation of development compared with animals of normal development at $24 \mathrm{~h}$ (D) and the anterior part of a larvae hatched at $72 \mathrm{~h}(\mathrm{E})$; scale bar $200 \mu \mathrm{m}$.

While this embryo showed appropriate development of the head and tail and also possessed pigmentation of the eye and the remaining body, the yolk sac exhibited turbidity and most importantly, 
the heart appeared to be smaller and thinner with malformed chambers and the presence of a pericardial oedema and there was no heartbeat (Figure 2C).

The hatching occurred in the control and solvent control animal until $72 \mathrm{~h}$ of exposure (Table 2). The hatching success was significantly reduced upon exposure to $0.61 \mathrm{mg} / \mathrm{L}$ OTA or higher OTA concentrations $(p=0.000)$. The inhibition of hatching reached an $\mathrm{EC}_{50}$ value of $0.44 \mathrm{mg} / \mathrm{L}$ OTA at $72 \mathrm{~h}$ of exposure $\left(\mathrm{y}=52.936 \mathrm{x}^{2}-154.9 \mathrm{x}+108.14, \mathrm{r}^{2}=0.92\right)$ and an $\mathrm{EC}_{50}$ value of $1.76 \mathrm{mg} / \mathrm{L}$ OTA after $96 \mathrm{~h}$ of exposure $\left(14.583 \mathrm{x}^{2}-106.25 \mathrm{x}+191.67, \mathrm{r}^{2}=1.00\right)$. At concentrations of $1.25 \mathrm{mg}$ OTA or higher no embryo was hatching.

Table 2. Summary of the hatching success for the respective test durations reported for all exposed embryos in the different treatments ( $n=24$ for each) and displayed as the percentage of the embryos still alive at this time point in brackets.

\begin{tabular}{ccc}
\hline Treatment & $\mathbf{7 2} \mathbf{h}$ & $\mathbf{9 6} \mathbf{h}$ \\
\hline contr & $83.3 \%(100 \%)$ & $83.3 \%(100 \%)$ \\
etoh & $95.8 \%(95.8 \%)$ & $100 \%(100 \%)$ \\
$0.16 \mathrm{mg} /$ L OTA & $95.8 \%(95.8 \%)$ & $100 \%(100 \%)$ \\
$0.31 \mathrm{mg} /$ L OTA & $79.2 \%(82.6 \%)$ & $37.5 \%(81.8 \%)$ \\
$0.63 \mathrm{mg} /$ L OTA & $16.7 \%(21.1 \%)$ & $4.2 \%(33.3 \%)$ \\
$1.25 \mathrm{mg} /$ L OTA & $0 \%(0 \%)$ & $0 \%(0 \%)$ \\
$2.50 \mathrm{mg} /$ L OTA & $0 \%(0 \%)$ & $0 \%(0 \%)$ \\
$5.00 \mathrm{mg} /$ L OTA & $0 \%(0 \%)$ & $0 \%(0 \%)$ \\
\hline
\end{tabular}

\subsection{Heart Rates}

After $48 \mathrm{~h}$ of exposure, heartbeats of the embryos were assessed (Figure 3). The solvent ethanol had no effect on the heart rates in the zebrafish embryos.

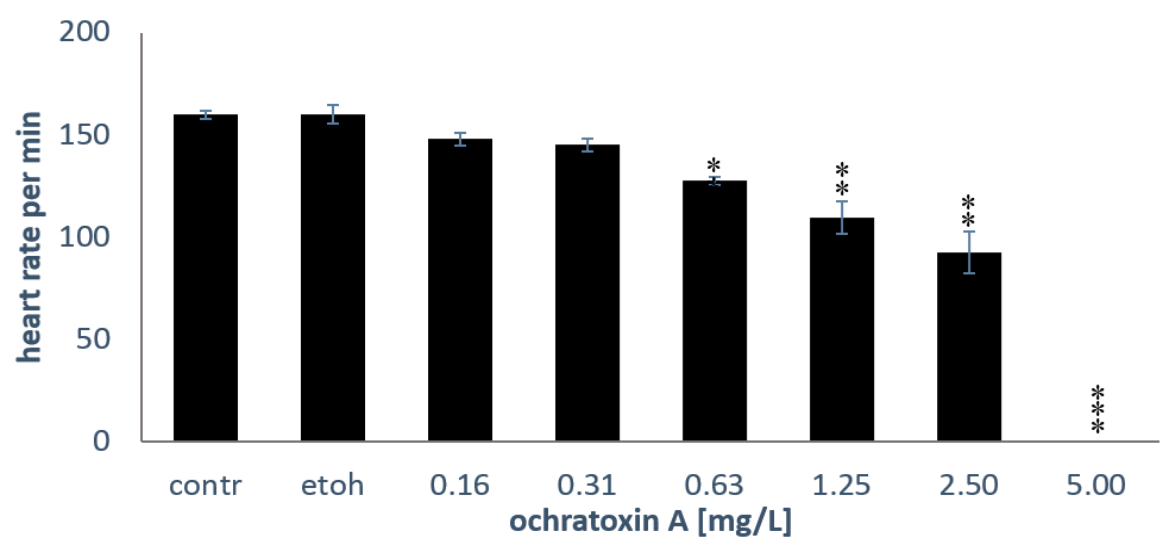

Figure 3. Heart rate of embryos. The mean \pm SEM of six embryos is shown after $48 \mathrm{~h}$ of exposure; the asterisks $\left(*: p<0.05 ;{ }^{* *}: p<0.01 ;{ }^{* * *}: p<0.001\right)$ indicate significant differences to the solvent control (etoh), Mann-Whitney U-tests with Bonferroni corrections for multiple comparisons, $n=6$ embryos per treatment.

Figure 4 shows that the heart rate per minute was also significantly reduced in embryos exposed to OTA for $72 \mathrm{~h}\left(p=0.002 ; \mathrm{EC}_{50}\right.$ of $\left.1.26 \mathrm{mg} / \mathrm{L}, \mathrm{y}=-20.353 \mathrm{x}^{2}-74.484 \mathrm{x}+176.56 ; \mathrm{r}^{2}=0.96\right)$. After $72 \mathrm{~h}$ of exposure, no embryo exposed to $2.5 \mathrm{mg} / \mathrm{L}$ OTA or higher showed any heartbeat. 


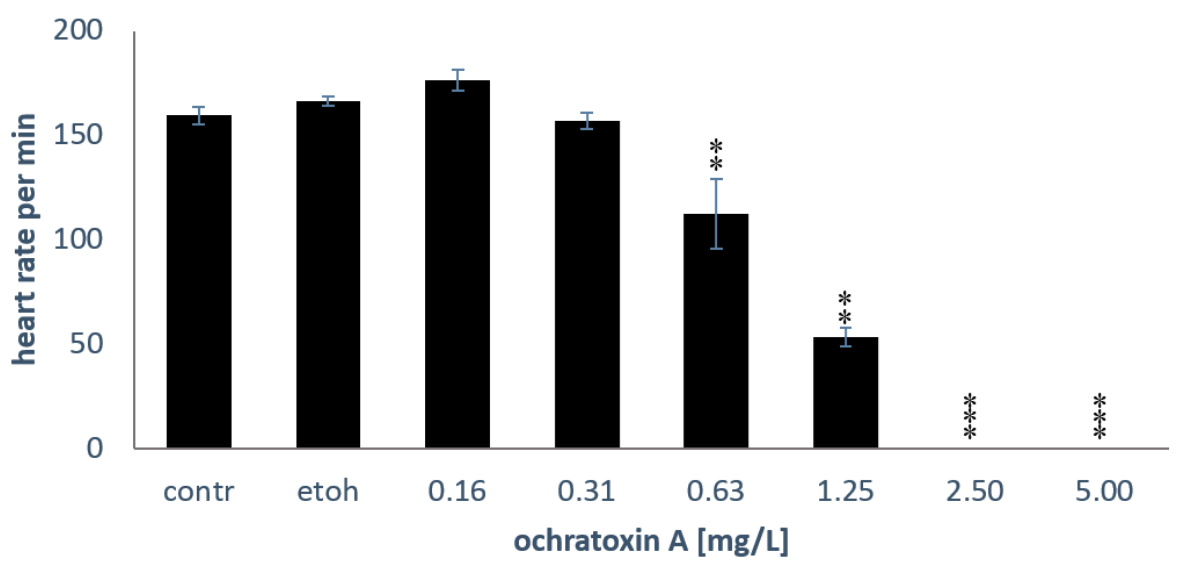

Figure 4. Heart rate of embryos. The mean \pm SEM of six embryos is shown after $72 \mathrm{~h}$ of exposure; the asterisks $\left({ }^{* *}: p<0.01 ;{ }^{* *}: p<0.001\right)$ indicate significant differences to the solvent control (etoh), Mann-Whitney U-tests with Bonferroni corrections for multiple comparisons, $n=6$ embryos per treatment.

\subsection{Oxidative Stress}

The measurement of oxidative stress in zebrafish embryos showed a significant increase of the emitted fluorescence units with increasing OTA concentrations ( $p=0.000$, Figure 5) which were found to be significantly different from the solvent control-treated embryos at concentrations of more than $0.078 \mathrm{mg} / \mathrm{L}$ OTA. The measurements of oxidative stress yielded an $\mathrm{EC}_{50}$ value of $0.067 \mathrm{mg} / \mathrm{L}$ OTA $\left(y=-46890 x^{2}+22883 x+181.71 ; r^{2}=0.96\right)$.

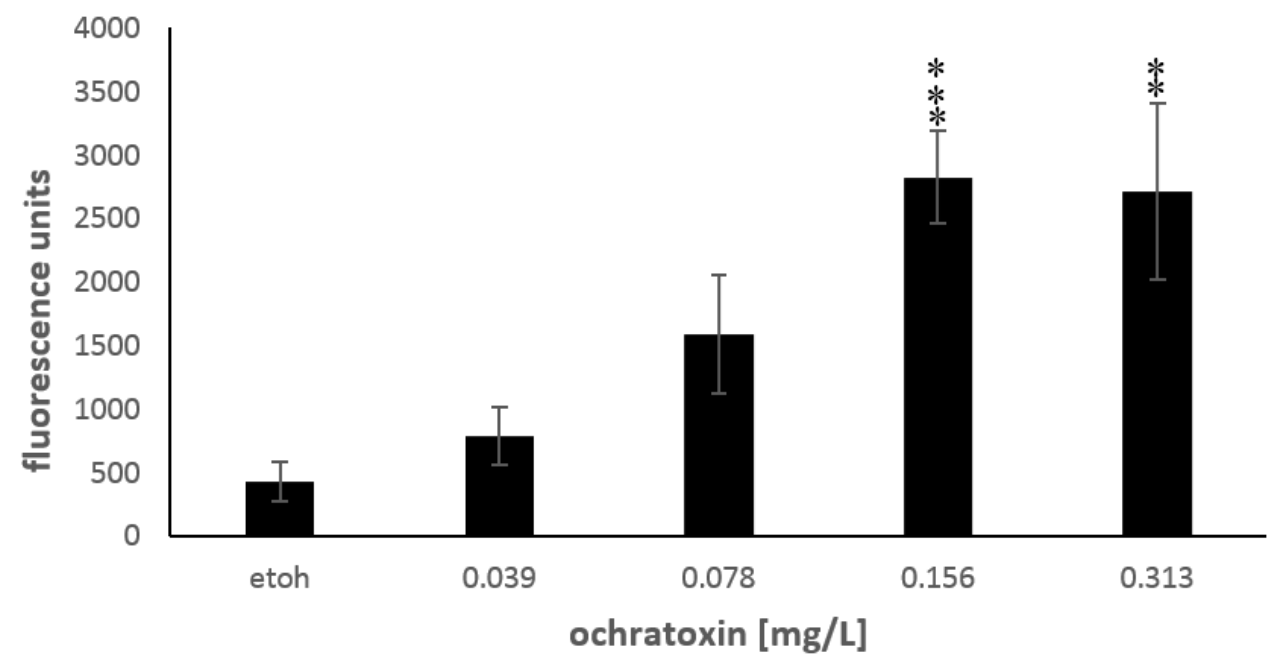

Figure 5. Concentration-dependent effects of OTA on oxidative stress in zebrafish embryos at $72 \mathrm{~h}$ of exposure displayed as fluorescence units emitted by the cell-permeant dye $2^{\prime}, 7^{\prime}$-dichlorodihydrofluorescein diacetate $\left(\mathrm{H}_{2} \mathrm{DCF}-\mathrm{DA}\right)$ upon excitation at $480 \mathrm{~nm}$; the asterisks $\left(^{* *}: p<0.01 ;{ }^{* * *}: p<0.001\right)$ indicate significant differences to the solvent control (etoh), Mann-Whitney U-test with Bonferroni corrections for multiple comparisons, $n=8-14$ embryos per treatment.

\subsection{3,4-Dichloroaniline}

Zebrafish embryos were sensitive to 3,4-Dichloroaniline (3,4-D) and showed impairment of development (Figure 6). The respective $\mathrm{LC}_{50}$ and $\mathrm{EC}_{50}$ values are displayed in Table 3.

As expected, the exposure to the reference compound 3,4-D resulted in mortality of the fish embryos (Table 3). After $24 \mathrm{~h}$ of exposure, significant damage occurred in embryos that had been 
treated with $4 \mathrm{mg} / \mathrm{L} 3,4-\mathrm{D}(p=0.000)$ but no significant increase of lethal damages. A LC 50 value of $9.06 \mathrm{mg} / \mathrm{L}$ OTA was noted at this time point. After $48 \mathrm{~h}$ of exposure, damaged embryos occurred resulting in an $\mathrm{EC}_{50}$ value of $2.09 \mathrm{mg} / \mathrm{L}\left(\mathrm{y}=19.444 \mathrm{x}^{2}-19.444 \mathrm{x}+5.5556, \mathrm{r}^{2}=1.00\right)$, whereas an $\mathrm{LC}_{50}$ value of $9.06 \mathrm{mg} / \mathrm{L}\left(\mathrm{y}=1.0101 \mathrm{x}^{2}-4.3434 \mathrm{x}+6.4646, \mathrm{r}^{2}=0.56\right)$ was noted. Exposure of the embryos to 3,4-D for $72 \mathrm{~h}$ and $96 \mathrm{~h}$ further decreased the $\mathrm{EC}_{50}$ and $\mathrm{LC}_{50}$ values (Table 3).

Table 3. Summary of the $\mathrm{LC}_{50}$ and $\mathrm{EC}_{50}$ values for the respective test durations for embryos exposed to 3,4-Dichloroaniline (3,4-D), $n=18$ for each 3,4-D concentration and the solvent control.

\begin{tabular}{cccc}
\hline Time Point & EC $_{\mathbf{5 0}}(\mathbf{m g} / \mathbf{L})$ & LC $_{\mathbf{5 0}}(\mathbf{m g} / \mathrm{L})$ & Ratio $\mathrm{LC}_{\mathbf{5 0}}$ to $\mathrm{EC}_{\mathbf{5 0}}$ \\
\hline $24 \mathrm{~h}$ & 3.47 & 9.06 & 2.61 \\
$48 \mathrm{~h}$ & 2.09 & 9.06 & 4.59 \\
$72 \mathrm{~h}$ & 2.22 & 6.08 & 2.74 \\
$96 \mathrm{~h}$ & 1.59 & 2.88 & 1.81 \\
\hline
\end{tabular}

Compared to OTA the reference compound 3,4-D caused different damages in the embryos. At $24 \mathrm{~h}$, the exposure to 3,4-D resulted in underdeveloped embryos (18.8\% of the damaged embryos) and deformations of embryos (75\% of the damaged embryos showing mainly missing eyes and deformations of the head). Only one damaged embryos showed underdevelopment and deformations. At 48 h of exposure to 3,4-D, 34.6\% of the embryos listed as damaged in Figure 6 showed yolk sac oedema and $46.2 \%$ of the embryos showed deformations and $19.2 \%$ of the impaired embryos showed both, oedema and deformations. The incubation of the embryos for $72 \mathrm{~h}$ with 3,4-D, 38.1\% of the embryos listed as damaged in Figure 6 showed yolk sac oedema and $42.9 \%$ of the embryos showed deformations, whereas $19.0 \%$ of the impaired embryos showed both, oedema and deformations. At this time point, only $11.1 \%$ of all embryos showed impairment of the heart beating. At $96 \mathrm{~h}$ of exposure $92.8 \%$ of the impaired but still alive embryos showed oedema and only $7.1 \%$ deformations. The hatching success was significantly reduced in embryos treated with $4 \mathrm{mg} / \mathrm{L} 3,4-\mathrm{D}$ after $72 \mathrm{~h}$ of exposure and significantly impaired by exposure to $2 \mathrm{mg} / \mathrm{L} 3,4-\mathrm{D}$ after $96 \mathrm{~h}$ of exposure. 

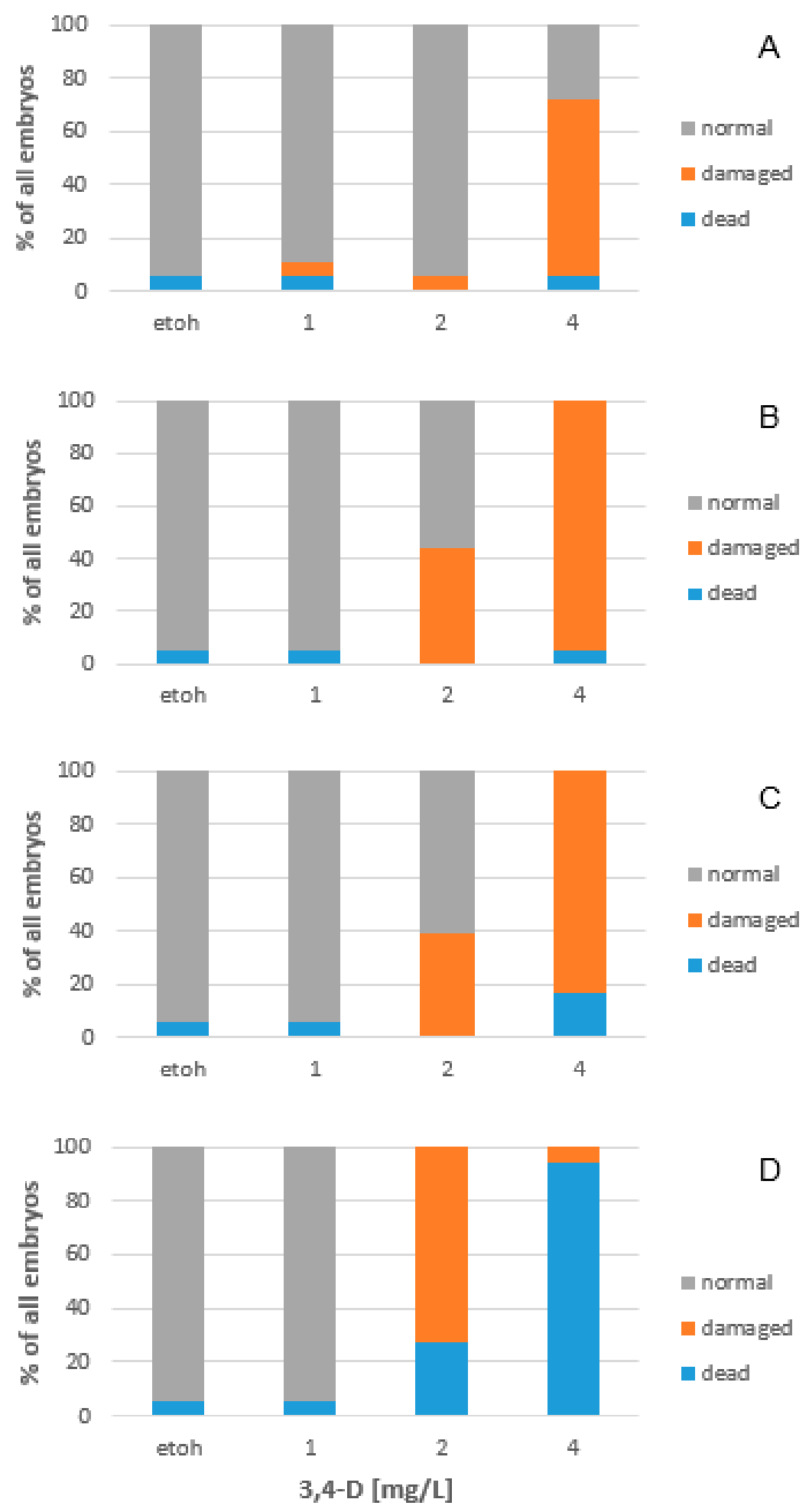

Figure 6. Concentration-dependent effects of 3,4-D on zebrafish embryos after 24 (A), 48 (B), 72 (C) and $96 \mathrm{~h}(\mathbf{D})$ of exposure. 


\section{Discussion}

\subsection{Toxicity of OTA to Fish Embryos}

Based on previous studies [26,27], the $\mathrm{LC}_{50}$ for OTA in different higher vertebrate species ranges from 2 and $58 \mathrm{mg} / \mathrm{kg}$ body weight. However, fish species appear to be more sensitive to OTA than higher vertebrates. If this is also true for the different structures of OTA (i.e., other ochratoxins or of their metabolites [28] remains unknown. The $\mathrm{LC}_{50}$ in adult seabass (Dicentrarchus labrax L.) after oral exposure was found to be at $9.23 \mathrm{mg}$ OTA per $\mathrm{kg}$ diet after $96 \mathrm{~h}$ of exposure which was calculated to be equal to an exposure value of $0.28 \mathrm{mg} / \mathrm{kg}$ body weight [18]. Investigations on rainbow trout showed a $\mathrm{LC}_{50}$ of $5.53 \mathrm{mg}$ OTA $\mathrm{kg}^{-1}$ body weight in this fish species after intraperitoneal injection [17]. A study on the embryo toxicity in zebrafish yielded even lower LC $_{50}$ values [16]. However, this study did not indicate the possible toxicological mechanisms that might be involved in OTA toxicity in zebrafish embryos. Therefore, low doses of OTA were again used in the present study to calculate more accurate $\mathrm{LC}_{50}$ values and describe the targets of OTA in fish embryos more in detail.

Increasing OTA concentrations clearly resulted in increased mortality of zebrafish embryos. Concentrations higher than $0.63 \mathrm{mg} / \mathrm{L}$ led to $100 \%$ mortality after $96 \mathrm{~h}$ of exposure. A LC $\mathrm{L}_{50}-\mathrm{Wert}$ value of $0.36 \mathrm{mg} / \mathrm{L}$ OTA was calculated after $96 \mathrm{~h}$ of exposure. Different effects on the zebrafish embryos were observed at even lower OTA concentrations and an $\mathrm{EC}_{50}$ value of $0.29 \mathrm{mg} / \mathrm{L}$ was obtained. Most of the embryos treated with OTA concentrations higher than $1.25 \mathrm{mg} / \mathrm{L}$ showed early retardation of development. In addition, it was observed that especially blood circulation and the heart development and heart rate were negatively affected by OTA exposure. In previous studies, cardiac abnormalities due to OTA exposure have only been described in rats and chickens [29,30]. Besides these effects, embryos exposed to lower OTA concentration more often showed yolk sac oedema and died at later points in time.

The present study showed higher $\mathrm{EC}_{50}$ and $\mathrm{LC}_{50}$ values than previously reported [16] and since especially the values for $24 \mathrm{~h}$ of exposure were found to be higher than those described by others [16]. However, the study of Haq and the co-authors [16] used no independently incubated embryos but reared 5 animals together in one replicate for their incubations and did not correct for multiple comparisons between the different treatments. Due to these experimental flaws, the present study is assumed to yield more realistic information on significant threshold levels for OTA toxicity in zebrafish. What is also noticeable when comparing the present study and the previous report [16] is that the present experiments yielded less deformations of the embryos. Moreover, the previously observed factor of 10 between $\mathrm{LC}_{50}$ and $\mathrm{EC}_{50}$ [16] was not confirmed by the present study. The reason for this might be the start of exposure that started at $<2 \mathrm{~h}$ post fertilization in the study conducted by Haq et al. [16] but at $3 \mathrm{~h}$ post fertilization in the present study.

OTA has been described as a frequent contaminant of diverse food and feed ingredients and can also be detected in processed animal feeds [1-3]. Maximum allowable levels for OTA have been established in Europe $(20 \mu \mathrm{g} / \mathrm{kg})$ and also in other regions [31]. The concentrations in finished animal feeds are often low but might be detrimental for fish if highly contaminated ingredients are used for feed production. High concentrations of OTA have been found in commonly used ingredients of fish feed in some cases, for example in corn (up to $1850 \mu \mathrm{g} / \mathrm{kg}$, [32]), wheat (up to $1024 \mu \mathrm{g} / \mathrm{kg}$, [33]) soybean and sunflower products (up to 350 and $240 \mu \mathrm{g} / \mathrm{kg}$, respectively [32]). In addition, inappropriate storage conditions for 6 weeks may lead to considerable amounts of OTA in commercial fish feeds (up to $400 \mu \mathrm{g} / \mathrm{kg}$, unpublished results of the authors). In addition, approximately $0.090 \mathrm{mg} / \mathrm{L}$ OTA have been reported in effluents from wine production and the time for biodegradation was relevant for the present study [8]. The present study, together with previous studies [16,18], demonstrated that even very low amounts of this mycotoxin can have detrimental effects on fish. 


\subsection{Detection of Reactive Oxygen Species (ROS)}

The measurement of oxidative stress in the zebrafish embryos showed a very low $\mathrm{EC}_{50}$ value of $0.067 \mathrm{mg} / \mathrm{L}$ OTA after $72 \mathrm{~h}$ of exposure. The detection of ROS in the embryos is therefore a very sensitive method to confirm that OTA is detrimental for zebrafish embryos. Oxidative stress has also been observed in OTA-treated rodents [34-36], although a link between ROS occurrence and detrimental effects, for example, renal toxicity was found to be low in an additional study on rats [37]. The mechanism by which OTA is able to increase ROS formation has not been fully explored so far. One possible explanation for increased ROS production and depletion of intracellular antioxidants in cells [38] might be the formation of a phenoxyl radical from OTA by peroxidases [39]. The presence of glutathione may lead to reconversion of the phenoxyl radical to OTA which generated a superoxide anion radical [40]. Superoxide anion radicals can lead to further oxidative stress by forming hydrogen peroxide and possible induction of a Fenton reaction and the subsequent formation of hydroxyl radicals resulting in further oxidative damage. Oxidative stress due to OTA exposure has been reported to lead to damage to lipids, proteins and DNA [36].

\subsection{Positive Controls}

The present study used 3,4-Dichloroaniline (3,4-D) as a positive control and at a concentration of $2.88 \mathrm{mg} / \mathrm{L}$, a mortality of $50 \%$ was observed after $96 \mathrm{~h}$ of exposure. This 3,4-D concentration therefore fulfilled the criteria for the early life stage test based on the revised OECD guideline [41]. In addition, the observed effects of 3,4-D on the embryos was comparable to the effects on survival and development in fish embryos and larvae [42,43], although the zebrafish embryos in the present study showed less pronounced effect on the heart function and the skeletal development than the early life stages of the rare minnow (Gobiocypris rarus, [43]).

\section{Conclusions}

OTA strongly interferes with the development of the early life stages of zebrafish. The toxicity assays revealed that OTA induced dose-dependent mortality in zebrafish embryos resulting in a $\mathrm{LC}_{50}$ value of $0.36 \mathrm{mg} / \mathrm{L}$ after $96 \mathrm{~h}$ of exposure. This confirms that OTA has detrimental effect on fish. The $\mathrm{EC}_{50}$ was calculated to be $0.29 \mathrm{mg} / \mathrm{L}$ for damage in the embryos. In addition, a correlation between the OTA concentrations and the decrease of the heart rates was observed. The assay for ROS production in OTA-treated embryos showed increased oxidative stress in treatments higher than $0.078 \mathrm{mg} / \mathrm{L}$ and was the most sensitive endpoint for detrimental effects of OTA in zebrafish embryos. The assays conducted indicate that OTA-related production of ROS contributed to the detrimental effects of this mycotoxin on zebrafish embryos. This indicates that the detection of ROS can be a useful tool to detect cellular influences of OTA on fish before potential morphological impairment occurs. However, the exact cellular mechanism(s) of action of OTA on cellular functions in different organs still remains to be investigated and further research is needed to provide an organ-wide description of possible effects of this mycotoxin.

\section{Materials and Methods}

\subsection{Chemicals}

All chemicals were obtained from Sigma-Aldrich (Buchs, Switzerland) unless indicated otherwise. The OTA (Sigma Cat. No. 01877; produced by Petromyces albertensi, lot No. 067M4011V) and 3,4-Dichloroaniline (Sigma Cat. No. 437778; lot No. 13509KQV) were solubilized in pure ethanol before use.

\subsection{Preparation of Exposure Medium}

ISO water [44] containing calcium chloride 2-hydrate $(294 \mathrm{mg} / \mathrm{L})$, magnesium sulfate-7-hydrate $(123.3 \mathrm{mg} / \mathrm{L})$, sodium hydrogen carbonate $(63 \mathrm{mg} / \mathrm{L})$ and potassium chloride $(5.5 \mathrm{mg} / \mathrm{L})$ was adjusted 
to a $\mathrm{pH}$ of 7.4 , sterile filtered and adjusted to a temperature of $27^{\circ} \mathrm{C}$ before use. OTA was solubilized in pure ethanol and added to the ISO medium at serial concentrations ranging from $5 \mathrm{mg} / \mathrm{L}$ to $0.039 \mathrm{mg} / \mathrm{L}$ (leading to a final ethanol concentration of $0.1 \%$ ethanol).

\subsection{Exposure of Fish Embryos}

The zebrafish eggs were obtained from the EAWAG (Dübendorf, Switzerland), whereas the ROS measurements were performed with zebrafish eggs obtained from the ZHAW brood stock that originated from EAWAG zebrafish adults. The test was conducted according to the DIN norm 38415-6 [44]. For each exposure concentration, 18-24 eggs were exposed and negative controls containing ethanol as a solvent were included. The solvent concentration did not exceed $0.1 \%$ in each of the treatments. The eggs were incubated at $27^{\circ} \mathrm{C}$ and a light/dark cycle of $16 \mathrm{~h}: 8 \mathrm{~h}$ in a Multitron Pro incubator (Infors AG, Bottmingen, Switzerland). The eggs were incubated with different ochratoxin concentrations at $3 \mathrm{~h}$ post fertilization in sterile ISO water containing $\mathrm{MgSO}_{4}, \mathrm{CaCl}_{2}, \mathrm{NaHCO}_{3}$ and $\mathrm{KCl}$ at a $\mathrm{pH}$ of 7.4. As a positive control, 3,4-Dichloroaniline (3,4-D) was used at concentrations between 1 and $4 \mathrm{mg} / \mathrm{L}$ as a positive control, since it was recommended by the revised OECD guideline as a new criterion for early life stage tests with zebrafish at a concentration of $4 \mathrm{mg} / \mathrm{L}$ of this substance resulting at least in a mortality of $30 \%$ after $96 \mathrm{~h}$ of exposure [41]. Determination of development of all embryos using a microscope (Leica Type 090-135.006, Leica Microsystems (Switzerland) AG, Heerbrugg, Switzerland) was conducted at $24,48,72$ and $96 \mathrm{~h}$ post fertilization.

\subsection{Assessment of Development}

For the experiment 4 plates with 4 embryos for each treatment were incubated for $96 \mathrm{~h}$ at $27^{\circ} \mathrm{C}$ whereby each plate contained the respective control exposures with eggs exposed to ISO water only and a solvent control containing the same ethanol content as the ochratoxin treatments $(0.1 \%)$. For the subsequent experiment evaluating ROS, 4 plates with 6 embryos for each treatment were incubated for $72 \mathrm{~h}$ at $27^{\circ} \mathrm{C}$. Mortality, developmental stage, including the presence of the eyes, somites and the movement of the tail and possible occurrence of oedema (Table 4) were noted after $24 \mathrm{~h}$ of exposure using a microscope (Leica-Microscope Type 090-135.006, Leica Microsystems (Switzerland) AG, Heerbrugg, Switzerland). After $48 \mathrm{~h}$ and $72 \mathrm{~h}$, pigmentation and blood flow were also assessed. Exact staging of the embryos was done according to Braunbeck and Lammer [25]. A dead embryo was noted if the material in the egg appeared to be at various stages of decomposition or coagulated. At the time points 48 and $72 \mathrm{~h}$ post fertilization the heartbeats of each living embryo were assessed for 20 to $30 \mathrm{sec}$ manually under the microscope and heartbeats per minute were calculated.

Table 4. Endpoints used for assessment.

\begin{tabular}{cc}
\hline Time Point & Endpoint \\
\hline $24 \mathrm{~h}$ & eye visible, somites, tail movements \\
$48 \mathrm{~h}$ & pigmentation, blood circulation, heartbeats, oedema, embryo movements \\
$72 \mathrm{~h}$ & pigmentation, blood circulation, heartbeats, oedema, embryo movements, hatching \\
$96 \mathrm{~h}$ & pigmentation, blood circulation, heartbeats, oedema, embryo movements, hatching \\
\hline
\end{tabular}

\subsection{Measurement of Reactive Oxygen Species (ROS)}

After $72 \mathrm{~h}$ of exposure, ROS production was measured using the fluorescent dye $2^{\prime}, 7^{\prime}$-dichlorodihydrofluorescein diacetate $\left(\mathrm{H}_{2} \mathrm{DCF}-\mathrm{DA}\right)$ as has previously been done in cell cultures of mammals and fish $[45,46]$. After exposure to OTA, the embryos were killed by an overdose MS-222 (150 mg/L in $\mathrm{NaHCO}_{3}$-buffered ISO medium), transferred to an opaque, flat-bottom 96-well plate and the medium was replaced by $100 \mu \mathrm{L}$ of $\mathrm{H}_{2}$ DCF-DA solution (final concentration: $5 \mu \mathrm{M}$ in ISO medium) was added to each well. The plate was incubated for $30 \mathrm{~min}$ at room temperature in the dark. Thereafter, fluorescence at excitation and emission wavelengths of $480 \mathrm{~nm}$ and $535 \mathrm{~nm}$, respectively, was measured with a plate reader (Infinite M200, Tecan Instruments, Männedorf, Switzerland). 


\subsection{Calculation of the $50 \%$ Level for Effects and Lethality}

The half maximal effective concentration $\left(\mathrm{EC}_{50}\right)$ was determined by plotting the responses of the embryos (including death) against the test concentrations. The relationship between the concentrations and the resulting effects followed polynomic equations which are reported for each duration of exposure separately including the respective correlation coefficients. For damages such as deformations and the occurrence of oedema, calculations of the concentration at which $50 \%$ of the effects were observed were conducted separately from the heart beat calculations and the measurements of oxidative stress. The concentration at which $50 \%$ of the embryos were found to be dead $\left(\mathrm{LC}_{50}\right)$ was calculated similarly.

\subsection{Statistics}

Chi-square statistics were employed to compare the incidence of damage to the embryos by using the Monte Carlo approximation (using 10,000 simulations, with confidence interval of $99 \%$ ) to the Pearson chi-square Test. The heartrates and fluorescence units were compared by using Mann Whitney U-tests and Kruskal Wallis tests (SPSS version 24 for Windows; SPSS Inc., Chicago, IL, USA). Differences between treatment groups were considered statistically significant when $p<0.05$ to which the according Bonferroni corrections for multiple comparisons were applied.

Author Contributions: Conceptualization, Methodology, C.P.; Investigation, L.T., S.S., and C.P.; Data Curation, L.T. and C.P.; Writing-Original Draft Preparation, C.P.; Writing-Review \& Editing, T.L.; Visualization, C.P.

Funding: This research received no external funding.

Acknowledgments: The authors thank Kristin Schirmer and Stephan Fischer (EAWAG, Dübendorf, Switzerland) for providing the zebrafish eggs for the tests. Furthermore, the language check of the manuscript by John Bennett is greatly acknowledged.

Conflicts of Interest: The authors declare that there are no conflicts of interest regarding the publication of this paper.

\section{References}

1. Binder, E.M.; Tan, L.M.; Chin, L.J.; Handl, J.; Richard, J.M.; Tan, L.M.; Chin, L.J.; Handl, J.; Richard, J. Worldwide occurrence of mycotoxins in commodities, feeds and feed ingredients. Anim. Feed Sci. Technol. 2007, 137, 265-282. [CrossRef]

2. Duarte, S.C.; Pena, A.; Lino, C.M. A review on ochratoxin A occurrence and effects of processing of cereal and cereal derived food products. Food Microbiol. 2010, 27, 187-198. [CrossRef] [PubMed]

3. Rodrigues, I.; Naehrer, K. Prevalence of mycotoxins in feedstuffs and feed surveyed worldwide in 2009 and 2010. Phytopathol. Mediterr. 2012, 51, 175-192.

4. Moss, M.O. Risk assessment for aflatoxins in foodstuffs. Int. Biodeterior. Biodegrad. 2002, 50, $137-142$. [CrossRef]

5. Manning, B.B.; Ulloa, R.M.; Li, M.H.; Robinson, E.H.; Rottinghaus, G.E. Ochratoxin A fed to channel catfish (Ictalurus punctatus) causes reduced growth and lesions of hepatopancreatic tissue. Aquaculture 2003, 219, 739-750. [CrossRef]

6. Reddy, L.; Bhoola, K. Ochratoxins-Food Contaminants: Impact on Human Health. Toxins 2010, 2, 771-779. [CrossRef] [PubMed]

7. Vlyssides, A.G.; Barampouti, E.M.; Mai, S. Wastewater characteristics from Greek wineries and distilleries. Water Sci. Technol. 2005, 51, 53-60. [CrossRef] [PubMed]

8. Nogueira, R.; Estevinho, I.; Abrunhosa, L.; Mendonc, C.; Machado, P.; Carballa, M.; Brito, A.G.; Venancio, A. Assessing the degradation of ochratoxin a using a bioassay: The case of contaminated winery wastewater. Water Sci. Technol. 2007, 56, 55-61. [CrossRef] [PubMed]

9. Duarte, S.C.; Lino, C.M.; Pena, A. Ochratoxin A in feed of food-producing animals: An undesirable mycotoxin with health and performance effects. Vet. Microbiol. 2011, 154, 1-13. [CrossRef] [PubMed] 
10. Boorman, G.A. NTP Technical Report on the Toxicology and Carcinogenic Studies of Ochratoxin A (CAS No. 303-47-9) in F344/n Rats (Gavage Studies); NIH Publication No. 89-2813; Department of Health and Human Services, National Institute of Health: Research Triangle Park, NC, USA, 1989.

11. Brown, M.H.; Szczech, G.M.; Purmalis, B.P. Teratogenic and toxic effects of ochratoxin A in rats. Toxicol. Appl. Pharmacol. 1976, 37, 331-338. [CrossRef]

12. Arora, R.G.; Froelein, H.; Fellner-Feldegg, H. Inhibition of ochratoxin A teratogenesis by zearalenone and diethylstilbestrol. Food Chem. Toxicol. 1983, 21, 779-783. [CrossRef]

13. Wiger, R.; Stormer, F.C. Effects of ochratoxins A and B on prechondrogenic mesenchymal cells from chick embryo limb buds. Toxicol. Lett. 1990, 54, 129-134. [CrossRef]

14. Hood, R.D.; Naughton, M.J.; Hayes, A.W. Prenatal effects of ochratoxin A in hamsters. Teratology 2005, 13, 11-14. [CrossRef] [PubMed]

15. O'Brien, E.; Prietz, A.; Dietrich, D.R. Investigation of the teratogenic potential of ochratoxin A and B using the FETAX system. Birth Defects Res. B Dev. Reprod. Toxicol. 2005, 74, 417-423. [CrossRef] [PubMed]

16. Haq, M.; Gonzalez, N.; Mintz, K.; Jaja-Chimedza, A.; De Jesus, C.L.; Lydon, C.; Welch, A.Z.; Berry, J.P. Teratogenicity of ochratoxin A and the degradation product, ochratoxin $\alpha$, in the zebrafish (Danio rerio) embryo model of vertebrate development. Toxins 2016, 8, 40. [CrossRef] [PubMed]

17. Doster, R.C.; Sinnhuber, R.O.; Pawlowski, N.E. Acute intraperitoneal toxicity of ochratoxin A and B derivatives in rainbow trout (Salmo gairdneri). Food Cosmet. Toxicol. 1974, 12, 499-505. [CrossRef]

18. El-Sayed, Y.S.; Khalil, R.H.; Saad, T.T. Acute toxicity of ochratoxin-A in marine water-reared sea bass (Dicentrarchus labrax L.). Chemosphere 2009, 75, 878-882. [CrossRef] [PubMed]

19. Bernhoft, A.; Høgåsen, H.R.; Rosenlund, G.; Ivanova, L.; Berntssen, M.H.G.; Alexander, J.; Sundstøl Eriksen, G.; Kruse Fæste, C. Tissue distribution and elimination of deoxynivalenol and ochratoxin A in dietary exposed Atlantic salmon (Salmo salar). Food Addit. Contam. Part A 2017, 34, 1211-1224. [CrossRef] [PubMed]

20. Lovell, R.T. Mycotoxins: Hazardous to Farmed Fish. Feed Int. 1992, 13, 24-28.

21. Zahran, E.; Manning, B.; Seo, J.-K.; Noga, E.J. The effect of Ochratoxin A on antimicrobial polypeptide expression and resistance to water mold infection in channel catfish (Ictalurus punctatus). Fish Shellfish Immunol. 2016, 57, 60-67. [CrossRef] [PubMed]

22. Srour, T.M. Effect of ochratoxin-A with or without Biogen ${ }^{\circledR}$ on growth performance, feed utilization and carcass composition of Nile tilapia (Oreochromis niloticus) fingerlings. J. Agric. Sci. Mansoura Univ. 2004, $29,51-61$.

23. Supamattaya, K.; Sukrakanchana, N.; Boonyaratpalin, M.; Schatzmayr, D.; Chittiwan, V. Effects of ochratoxin A and deoxynivalenol on growth performance and immuno-physiological parameters in black tiger shrimp (Penaeus monodon). Songklanakarin J. Sci. Technol. 2005, 27 (Suppl. 1), S91-S99.

24. Hauptman, B.S.; Barrows, F.T.; Block, S.S.; Gaylord, T.G.; Paterson, J.A.; Sealey, W.M. Potential for a mycotoxin deactivator to improve growth and performance of rainbow trout fed high levels of an ethanol industry co-product, grain distiller's dried yeast. N. Am. J. Aquac. 2014, 76, 297-304. [CrossRef]

25. Braunbeck, T.; Lammer, E. Background Paper on Fish Embryo Toxicity Assays; German Federal Environment Agency: Dessau-Roßlau, Germany, 2006; p. 298.

26. Kuiper-Goodman, T.; Scott, P.M. Risk assessment of the mycotoxin ochratoxin A. Biomed. Environ. Sci. 1989, 2, 179-248. [PubMed]

27. Peckham, J.; Doupnik, B.J.; Jones, O.J. Acute toxicity of ochratoxins A and B in chicks. Appl. Microbiol. 1971, 21, 492-494. [PubMed]

28. Heussner, A.H.; Bingle, L.E.H. Comparative ochratoxin toxicity: A review of the available data. Toxins 2015, 7, 4253-4282. [CrossRef] [PubMed]

29. Okutan, H.; Aydin, G.; Ozcelik, N. Protective role of melatonin in ochratoxin A toxicity in rat heart and lung. J. Appl. Toxicol. 2004, 24, 505-512. [CrossRef] [PubMed]

30. Jameel, F.A. Pathological effects of ochratoxin A in brain, heart and lung of chicks. Al-Anbar J. Vet. Sci. 2011, 4, 93-98.

31. Van Egmond, H.P.; Jonker, M.A. Worldwide Regulations for Mycotoxins in Food and Feed in 2003; Food and Nutrition Paper No. 81; Food and Agriculture Organization (FAO): Rome, Italy, 2004.

32. Rafai, P.; Bata, A.; Jakab, L.; Vanyi, A. Evaluation of mycotoxin contaminated cereals for their use in animal feeds in Hungary. Food Addit. Contam. 2000, 17, 799-808. [CrossRef] [PubMed] 
33. Czerwiecki, L.; Czajkowska, D.; Witkowska-Gwiazdowska, A. On ochratoxin A and fungal flora in polish cereals from conventional and ecological farms. Part 2: Occurrence of ochratoxin A and fungi in cereals in 1998. Food Addit. Contam. 2002, 19, 1051-1057. [CrossRef] [PubMed]

34. Schaaf, G.J.; Nijmeijer, S.M.; Maas, R.F.M.; Roestenberg, P.; de Groene, E.M.; Fink-Gremmels, J. The role of oxidative stress in the ochratoxin A-mediated toxicity in proximal tubular cells. Biochim. Biophys. Acta 2002, 1588, 149-158. [CrossRef]

35. Sorrenti, V.; Di Giacomo, C.; Acquaviva, R.; Barbagallo, I.; Bognanno, M.; Galvano, F. Toxicity of ochratoxin A and its modulation by antioxidants: A review. Toxins 2013, 5, 1742-1766. [CrossRef] [PubMed]

36. Tao, Y.; Xie, S.; Xu, F.; Liu, A.; Wang, Y.; Chen, D.; Pan, Y.; Huang, L.; Peng, D.; Wang, X.; Yuan, Z. Ochratoxin A: Toxicity, oxidative stress and metabolism. Food Chem. Toxicol. 2018, 112, 320-331. [CrossRef] [PubMed]

37. Zhu, L.; Yu, T.; Qi, X.; Gao, J.; Huang, K.; He, X.; Luo, H.; Xu, W. Limited link between oxidative stress and ochratoxin A-Induced renal injury in an acute toxicity rat model. Toxins 2016, 8, 373. [CrossRef] [PubMed]

38. Kamp, H.G.; Eisenbrand, G.; Schlatter, J.; Wurth, K.; Janzowski, C. Ochratoxin A: Induction of (oxidative) DNA damage, cytotoxicity and apoptosis in mammalian cell lines and primary cells. Toxicology 2005, 31, 413-425. [CrossRef] [PubMed]

39. Longoria, A.; Tinoco, R.; Vazquez-Duhalt, R. Chloroperoxidase-mediated transformation of highly halogenated monoaromatic compounds. Chemosphere 2008, 7, 485-490. [CrossRef] [PubMed]

40. El Adlouni, C.; Pinelli, E.; Azemar, B.; Zaoui, D.; Beaune, P.; Pfohl-Leszkowicz, A. Phenobarbital increases DNA adduct and metabolites formed by ochratoxin A: Role of CYP 2C9 and microsomal glutathione-S-transferase. Environ. Mol. Mutagen. 2000, 35, 123-131. [CrossRef]

41. EURL ECVAM (European Commission European Union Reference Laboratory for Alternatives to Animal Testing). Recommendation on the Zebrafish Embryo Acute Toxicity Test Method (ZFET) for Acute Fish Testing Toxicity; EUR 26710—Joint Research Centre-Institute for Health and Consumer Protection; EUR—Scientific and Technical Research Series; Publications Office of the European Union: Luxembourg, 2014; p. 34.

42. Nagel, R.; Bresch, H.; Caspers, N.; Hansen, P.D.; Markert, M.; Munk, R.; Scholz, N.; ter Höfte, B.B. Effect of 3,4-dichloroaniline on the early life stages of the zebrafish (Brachydanio rerio): Results of a comparative laboratory study. Ecotoxicol. Environ. Saf. 1991, 21, 157-164. [CrossRef]

43. Zhu, B.; Liu, T.; Hu, X.; Wang, G. Developmental toxicity of 3,4-dichloroaniline on rare minnow (Gobiocypris rarus) embryos and larvae. Chemosphere 2013, 90, 1132-1139. [CrossRef] [PubMed]

44. DIN Norm 38415-6 T6. German Standard Methods for the Examination of Water, Waste Water and Sludge_Subanimal Testing (Group T)—Part 6: Toxicity to Fish; Determination of the Non-Acute-Poisonous Effect of Waste Water to Fish Eggs by Dilution Limits (T 6); Deutsches Institut für Normung e.V.: Berlin, Germany, 2001.

45. Gauron, C.; Rampon, C.; Bouzaffour, M.; Ipendey, E.; Teillon, J.; Volovitch, M.; Vriz, S. Sustained production of ROS triggers compensatory proliferation and is required for regeneration to proceed. Sci. Rep. 2013, 3, 2084. [CrossRef] [PubMed]

46. Pietsch, C.; Noser, J.; Wettstein, F.E.; Burkhardt-Holm, P. Unraveling the mechanisms involved in zearalenone-mediated toxicity in permanent fish cell cultures. Toxicon 2014, 88, 44-61. [CrossRef] [PubMed]

(C) 2018 by the authors. Licensee MDPI, Basel, Switzerland. This article is an open access article distributed under the terms and conditions of the Creative Commons Attribution (CC BY) license (http:// creativecommons.org/licenses/by/4.0/). 